18. Paslavska, A. (2005). Negation as a language universal: principles, parameters, functioning. Lviv: Vyd. tsentr Lviv. nats. un-tu im. I. Franka [in Ukrainian].

sian].

19. Slavic antiquities: An ethnolinguistic dictionary (1995 - 2004): V 5 t. Moskva: Mezhdunarodnue otnoshenyia [in Rus-

20. Slukhai (Molotaeva), N.V. (2006). Symbol in the circle of adjacent and closely related concepts. Slovo. Symvol. Tekst: Sbornyk nauchnыkh trudov, posviashchennыkh 80-letyiu prof. M.A. Karpenko. Kyev. $172-183$ [in Russian].

21. Fil, H.\& Tsupyk, A. (2017). Verbal symbols of phraseological units of the Ukrainian language as an important factor in the creation of a national-cultural picture of the world. Aktualni pytannia humanitarnykh nauk. 17. $154-160$ [in Ukrainian].

22. Frazeolohichnyi slovnyk ukrainskoi movy (1999). Kyiv: Naukova dumka, [in Ukrainian].

23. Shchekyn, H.V. (2011). Visual psychodiagnostics: knowledge of people by their appearance and behavior. Kyev: Yzdat. dom "Personal" [in Russian].

24. Shynkaruk, V., Salata, H. \& Danylova, T. (2018). Myth as a phenomenon of culture. Visnyk Natsionalnoi akademii kerivnykh kadriv kultury i mystetstv. 4. 17 - 22. [in English].

Стаття надійшла до редакції 06.11.2018 p.

UDC 316.4

Danilyan Oleg
Doctor of Philosophical Sciences, Professor,
Head of the Department of Phylosophy of
Yaroslav Mudryi National Law University
ORCID 0000-0001-5308-4664
odana@i.ua
Dzoban Alexander
Doctor of Philosophical Sciences, Professor
Philosophy Department
Yaroslav Mudryi National Law University
ORCID 0000-0002-2075-7508
a_dzeban@ukr.net
Kalinovsky Yury
Doctor of Philosophical Sciences, Professor
Philosophy Department
Yaroslav Mudryi National Law University
ORCID 0000-0002-0081-8107
kalina_uu@ukr.net

\title{
MAN IN INFORMATIONAL SOCIETY: FROM MORAL IDENTIFICATION TO MORAL IDENTITY
}

Purpose: to comprehend the peculiarities of the phenomenon of moral identification of a man in conditions of the information society. Methods: the whole complex of philosophical general scientific and specific methods inherent in philosophical research, in their interconnection and complementarity. The research methodology is based on the principles of system and structural-functional analysis. Scientific novelty: information society is an unlimited space for self-designing of a person, on the one hand, expanding the space of identification, and on the other hand - narrowing the very identity by choosing the ways and forms of self-identification. This conditions the emergence of polyidentity which leads to the instability of the socio-cultural space of the information society. Conclusions: the problem of identification of a man in a changing world-view paradigm of the information society is relevant and requires at the philosophical level the development of settings that help an individual to maintain his identity under the intense influence of information flows. In the process of acquiring moral identity by a person in the information society, communication becomes of particular importance.

Keywords: moral; identity; identification; information society; communication; information technologies; social institutions.

Данильян Олег Геннадійович, доктор фрілософрських наук, професор, завідувач кафедри фрілософрії Національного юридичного університету імені Ярослава Мудрого; Дзьобань Олександр Петрович, доктор фрілософрських наук, професор кафредри фрілософрії Національного юридичного університету імені Ярослава Мудрого; Калиновський Юрій Юрійович, доктор фрілософрських наук, професор кафредри фрілософрії Національного юридичного університету імені Ярослава Мудрого

Людина в інформаційному суспільстві: від моральної ідентифікації до моральної ідентичності

Мета: осмислити особливості феномену моральної ідентифікації людини в умовах інфрормаційного суспільства. Методи: весь комплекс філософських, загальнонаукових та специфічних методів, властивих філософським дослідженням, в їх взаємозв'язку і взаємодоповнюваності. Методологія дослідження базується на принципах системного та структурнофункціонального аналізу. Наукова новизна: інфрормаційне суспільство є необмеженим простором для самоконструювання особистості, з одного боку, розширюючи простір ідентифрікації, а з іншого - звужуючи саму ідентичність за рахунок вибору способів і фрорм самоідентифікації. Це зумовлює появу поліідентичності, яка призводить до нестабільності соціокультурного простору інформаційного суспільства. Висновки: проблема ідентиффікації людини в умовах мінливої світоглядної парадигми інформаційного суспільства $є$ актуальною і вимагає вироблення на філософсьькому рівні установок, які допомагають індивіду зберегти свою тотожність під інтенсивним впливом інформаційних потоків. У процесі набуття людиною моральної ідентичності в інформаційному суспільстві особливого значення набуває комунікація.

(C) Danilyan O., 2019

(c) Dzoban A., 2019

(c) Kalinovsky Yu., 2019 


\footnotetext{
Ключові слова: мораль; ідентичність; ідентифікація; інформаційне суспільство; комунікація; інфрормаційні технології; соціальні інститути.
}

Данильян Олег Геннадьевич, доктор фрилософрских наук, профессор, заведующий кафедрой фрилософии Национального юридического университета имени Ярослава Мудрого; Дзебань Александр Петрович, доктор философрких наук, профрессор кафедры философии Национального юридического университета имени Ярослава Мудрого; Калиновский Юрий Юрьевич, доктор философрских наук, профессор кафедры философии Национального юридического университета имени Ярослава Мудрого

Человек в информационном обществе: от моральной идентификации до моральной идентичности

Цель: осмыслить особенности феномена нравственной идентификации человека в условиях информационного общества. Методы: весь комплекс философских, общенаучных и специальных методов, присущих философским исследованиям, в их взаимосвязи и взаимодополняемости. Методология исследования базируется на принципах системного и структурнофункционального анализа. Научная новизна: информационное общество является неограниченным пространством для самоконструирования личности, с одной стороны, расширяя пространство идентификации, а с другой - сужая идентичность за счет выбора способов и форм самоидентификации. Это обуславливает появление полиидентичности, которая приводит к нестабильности социокультурного пространства информационного общества. Выводы: проблема идентификации человека в условиях меняющейся мировоззренческой парадигмы информационного общества является актуальной и требует выработки на фрилософском уровне установок, которые помогают индивиду сохранить свою тождественность под интенсивным воздействием информационных потоков. В процессе приобретения человеком нравственной идентичности в информационном обществе особое значение приобретает коммуникация.

Ключевые слова: мораль; идентичность; идентификация; информационное общество; коммуникация; информационные технологии; социальные институты.

Introduction. The information society is the society in which intense ideological transformations take place, where informatization becomes the main value, as well as the related crisis simulation and virtualization that stimulate changes in the axiological priorities, relationships and communication of people. At the same time, the very value of a human person is reduced due to the prevalence of the aspects of utilitarianism and pragmatism, both in contacts, and in the information that a person has. In such conditions, the problem of identification of a person, his/her worldview space and social being, the choice of moral and life goals and means becomes of particular relevance. Under the influence of the growing process of informatization of all aspects of the individual's life, there is a re-accentuation of the value, moral and spiritual components of human worldview, transformation of traditional forms of communication, and complication of the systemic connections of social subjects. As a result, the problem of identification, which is a multivectored philosophical phenomenon, which determines the special work of self-awareness and allows an individual to determine his/her identity and social-personal area, appears in a new way.

The results of the scientific sources analysis indicate that the emergence of identitification and identity issues is traditionally associated with psychological studies. In the forties of the last century, E.Erickson offered in his conceptions the terms "identity", "crisis of identity". In the fifties various interpretations of these concepts appeared. Further evolution of the problem of identity from the appearance of the first germinal theoretical forms to the independent theoretical knowledge can be traced in the works of the classics of foreign philosophy, psychology and sociology of W. James, Z. Freud, K. Young, J. Piaget, E.Fromm, G. Mead, Ch. Cooley, E. Erickson, A. Maslow, R. Meili, J. Habermas, K. Horney and many other researchers.

In modern scientific researches, experts pay attention to the various aspects of human existence in the information society, affecting his/her moral identitification and identity. The problem of moral choice of a person remains one of the leading in scientific studies of the present. Thus, the researchers $G$. Kahane, J.Everett, B. Earp define the peculiarities of the utilitarian approach to the ethical problems, analyze the correlation of utilitarian and moral factors in the process of man's making the fateful solutions [1]. In turn, G.Greene studies the essence of moral cognition, its features and forms of expression. This author emphasizes certain differences in the interpretation of moral norms in various cognitive and civilizational systems [2], which respectively affects the moral identification and moral identity of an individual.

Instead, M. Barth, F. Yugert, M. Wutzler, and I. Fritsche emphasize the peculiarities of global identity and the spread of absolute moral standards as two important factors of solidarity and realization of collective actions. Scientists prove that the consequence of the global identity is the spread of general moral standards that relate to inter-group solidarity and indirectly affect the nature of collective actions [3]. Accordingly, the global identity is based on the opportunities provided by the information society, that facilitate the "exchange" of moral values and patterns of behavior, both moral and immoral.

The researchers D. May, Y. Chang, R. Shao try to combine theoretical and practical aspects of moral identification. In particular, they proposed a new form of moral identification, which directly affects the understanding of business ethics. The problem of morality in this research is considered through the prism of human behavior in a particular professional group, that is, the emphasis is made on the so-called "practical morality" [4].

A number of experts analyze the interrelation of moral identity with other types of identity - political, legal, national, etc. Thus, from F. Turner-Zwinkels, M. van Zomeren and M. Postmes' point of view, moral identity plays a significant role in shaping the political identity of a man. Moral individuality is correlated with the political identity and involves the idea of self-restraint of a citizen both in politics and in manifestations of party activity [5]. 
At the same time, the study of this problem suggests that, despite the solid existing theoretical basis of the studied phenomena, their reflection in the conditions of the information society needs to be clarified taking into account new information and technological processes.

The purpose of the article is an attempt to comprehend some features of the phenomenon of moral identification of a personality in the conditions of the information society.

Findings. The study of identification is not a similar to the study of identity. The latter includes the acquisition of real qualities of a personality, and identification is a description of these qualities. Identity is the result, that is, defending and protecting oneself; identification is adaptation, the process of constant choice, adoption of norms, traditions, settings. Therefore, at each level of description of the identity comprehension the identification process preceeds.

In philosophical studies, identification is understood as the supreme form of socialization, the way of communication of a man with the social environment through "the acts of tying and identifying oneself with the collective entities of one's local civilization, culture, historical epoch. In this sense, identity manifests all the main symbols of the inclusion of an individual into the community" [6,37]. At the same time, moral identification is the acquisition by a person of his moral "Self", through the establishment and approval of freedom and dignity. As a man lives in the world of tense ideological and social motivations, the process of identification solves at one time a lot of problems of an individual, and through them - of the society itself: a person finds existence which is identical with his/her spiritual essence; gets the opportunity to solve the problem of loneliness and historical continuity. However, in the information society, acquiring identity is not relevant to the community, but the desire to escape, to avoid social relations, which is connected with the instability of a person as an element in the structure of society. Its main determinants are the processes of individualization and personalization that arise as a result of the change of meaningful orientations, which gives grounds for the formation of a self-deterministic subject who feels the need to "find" himself and establish new boundaries of his existence.

Internet services and technologies allow users of different beliefs, of different backgrounds and level of education to establish contact with each other and unite in the communities. At the same time, in such an environment, there are problems with the identification and anonymity of the users who challenge their ability to understand their livelihoods (both private and professional) and dispose of it in a virtual environment where the new rules appear. The emergence of the "Internet of Things" also raises an important problem of identity in the context of the relationship of "man-machine."

In the information environment, a person faces several types of identity that are exposed to positive and negative changes under the influence of information and communication technologies (ICTs). The main of these are two types of identity: ipse-identity (self-perception) and idem-identity (more formal identity depending on the context, environment and situation). Defenders of privacy and human rights emphasize, above all, the threat of ipse-identity. Computers accumulate knowledge, create profiles, contributing to the idem-identity of the user, who does not suspect about these profiles and how they affect his/her ipseidentity. It significantly affects the positive freedom of an individual, since the world with which he interacts has already been chosen for him [7].

Modern developments of domestic researchers in the field of philosophy and law give grounds for reasoning in favor of the creation of a new right, namely, the right to protection of identity. This right should not be formulated as negative and should be aimed at protecting the ipse-identity itself.

The morally motivated approach is to enable the information society to strengthen ipse-identity as the starting point for idem-identity. Such strengthening would stimulate responsibility, since then an individual would be recognized, but not his profiles [8]. It should be considered that the key to this responsibility is data protection, since a person must control the personal data in order to be able to act through his or her ipseidentity.

Information processes, forming an eclectic, fragmentary socio-cultural space, transform the ideological paradigm, and at the same time, contribute to the development of creativity, while changing the horizons of individual being, determine the information identity of man. Modern man acts as an active personality, which manifests one's personal qualities in the process of symbolic consumption, one of the ways of creating the so-called moral I-image [9-10]. The process of individualization is characterized by the wish of man to be oneself and to have the opportunity of free choice, to position oneself in society in one's own way and to form an individual social space, to bear responsibility for one's own life and to optimally dispose of one's ethical, emotional, physical, experience, to be an independent person. In this connection E.Trufanova notes, "We see that the conditions of modern society offer a lot of possible identifications, each of which allows a person to create a certain I-image. ... Crisis identity is expressed in the violation of the connections between the various I-images, in the fact, that some l-images do not fit into the existing system, and the reformation is required, the restructuring of I" [11,21].

The paradox of the information society itself is also expressed in the different polar interpretations of the phenomenon of "isolation", which is one of the segments of identity: on the one hand, informatization of society unites people, on the other hand, it transforms it into the society of total loneliness more and more [12-14]. The peculiarities of the interaction of people in such a society are their superficial nature, since real communication is superseded by unrealistic, virtual. Information communicativeness that provides the 
availability of diverse information and the real disunity of people come into conflict, create the problems of subjectivity, personal choice of information and its transformation into behavioral regulativa, exacerbate the problem of deformation of universal values [11, 21].

Information technologies serve to integrate the world in the global networks and at the same time contribute to the destruction of communication ethnic, religious barriers. As a result of the formation of a direct link of an individual with the source of information, there is an intensification of the process of personalization, when a person becomes less dependent on the generally accepted, traditional thought in the perception and interpretation of the information. The main factor in the process of personalization is the blurring of social roles, the destruction of former identities, as a result of which, as G. Lipovetsky points out, a man appears as "a floating space that does not have either a permanent place or any guiding marks" [15, 99]. Growing in the information society, the process of individualization acts as the liberation of a man from social preconditions. Society as a system that provides strong forms to the social identity is destroyed, and the living space shapes the new forms of identity, new communities, the borders between which become easily penetrative and mobile. In such conditions, human identity changes from the given into the task that a man himself must decide. There appears a creative subject who, in the situation of destruction of the previous grounds for self-categorization, constructs new social relations and his own identity.

The information society is an unlimited space for self-designing of a person, on the one hand, expanding the space of identification, and, on the other hand, narrowing the very identity by choosing increasingly narrower cultural lacunae for self-identification. The latter often leads to the fragmentation of human self and the emergence of poly-identity, which sometimes acts as a norm, due to which the sociocultural space of the information society becomes unstable. This, in turn, leads to an increase in the lives of people of various kinds of simulacres - the images of reality that replace reality itself, "local cultures and identities lose their roots and are replaced by symbols of the commodity world, taken from the advertising and image design of multinational concerns. Being becomes a design, and besides everywhere. People are what they buy (or can buy)" $[16,82]$. Society absorbs the idea that the process of consumption, which is currently continuing with the purchase of goods, is a natural algorithm of human life, and things are the means of implementation and approval of human personality, which shows with this special creative qualities. The satisfaction of individually mediated needs is accompanied by the emergence of new value guideng marks, such as heartfullness, trust, sincerity. This aspect of individualization, according to a fair observation by N. Sitkevich, "relates to the wish of man to be himself, to act as the creator of various social forms of activity, to receive the freedom of expression in accordance with his intentions, to dispose of his personal emotional experience, to be identical to himself" [17, 47].

The simulation of social institutions, as it was repeatedly mentioned in the previous publications by the author, serves as a factor and a symptom of degradation of society, which purchase the features, the description of which leads us to use the notion of virtual reality and foresees the interaction of a man not with the things, but with their images. A person of the information society is immersed in the virtual reality of simulations, and increasingly perceives the world as a gaming environment, being aware of its conventionality, the manageability of its parameters and the ability to exit from it. In Johann Huizinga's conception, gaming is one of the main archetypes of human expression and interaction. He even introduced into the social philosophy the term Homo ludens (a gaming person) [18]. Such person loses the individuality, and only the role-identity is left, a person has a desire for absolute self-copying. That is why, Baudrillard calls the socio-cultural space "a photocopier of culture". He names cloning as an example of "narcissistic necrosis"; in fact, it is the same photocopier, only a person photocopies oneself. At the same time, interestingly, the masses "are also a clone unit, which works from identical to identical, without resorting to another" $[19,298]$. Consequently, such a person is not capable of distinction, of the necessary for the real identification "identifying" with oneself.

Perhaps, identity is a product of the principle of simulation, under which all signs can be exchanged for each other, but not be exchanged for anything real. "Now all are separated and indifferent under the power of television and the car, under the power of behavior patterns that are reflected in everything - in media broadcasts or in planning cities. Everything is built in a row and everyone unknowingly identifies oneself with skilfully positioned guided simulation models. All allow mutual substitution, as well as these models. This is the era of individuals with a variable geometry, but the geometry of the code remains unchanged and centralized. In fact, the form of social relations is shaped by a monopoly of code, defusingly present in all tissues of the cities" [20, 157-158]. The "surplus" of semblance characteristic of the information society leads, as P. Kozlovsky wrote, to the destruction of the scene of known, the sphere of expression, the full transparency and impersonality of the actors, that is, to the loss of "Self" [21, 59].

The striving of a man to get out from the limits of his natural essence imposes an imprint on the changes not only in the environment, but also in the purely human environment. In a new virtual space, a person becomes a kind of a prism through which one or another reality, or an event series is viewed. Therefore, in solving social problems aimed at the good of human existence, the direct participation of a person oneself is necessary. Thus, J. Habermas emphasizes that the rotation of the worldview of the information society contributes to changing the characteristics of identity, "the understanding by a person of one's self depends not only on how he/she describes him/herself, but also on the samples he/she observes. 
Self-identity of I at the same time is determined by how people see themselves and what they would like to see themselves" [22, 7]. Realizing oneself as the subject of activity, a person accepts the authorship of his/her social life and the moral responsibility for it. According to the established level of trust, a person takes either an active or passive life position.

Communication plays an important role in gaining moral identity by a person in the information society. It is in the process of interpersonal communication that he/she receives additional information about oneself, and when comparing oneself with a number of other people, a person can understand oneself and realize what he/she really is. J. Habermas notes that the identity of a person is formed through selfidentification, which received an intersubjective recognition. The basis of moral identity is self-identification, that is, a look into one's inner world and finding oneself at any moment, therefore, the individual reflects him/herself reluctantly to understand oneself [22-24].

Conclusions. In the information society, the values acquire a brightly expressed hedonistic and utilitarian character. Information frameworks also limit the meaning of values, they are simplified and narrowed. That is why, in comparison with the traditional system of moral values, which are certain determinants of the process of identification, the moral values of the information society are inverted and inversed. A person of the information society is less burdened with the load of the formed and historically determined stereotypes; he/she has more mobile responses and the ability to manipulate any strata of information. One can say that he/she acquires a new abstract form of one's own existence.

Thus, the problem of identifying a person in a changing world-view paradigm of the information society is relevant and requires at the philosophical level the development of settings that help an individual to save the own identity under the intense influence of information flows.

In this regard, given the extraordinary importance and urgency, the issues of moral identification of a person in the information society should be considered rather promising for further research both in the field of separate sciences (sociology, psychology, conflictology), and at the level of philosophical generalization. In addition, the stated problem should be taken into account in a broader view in the practical sphere: in the sphere of education (state level), in the activities of local authorities (local level), etc.

\section{תimepamypa}

1. Kahane G., Everett J., Earp B. Utilitarian judgments in sacrificial moral dilemmas do not reflect impartial concern for the greater good. Cognition. 2015. Vol. 134. P. 193-209.

2. Greene JD. The rise of moral cognition. Cognition. 2015. Vol. 135. P. 39-42.

3. Barth M., Jugert P., Wutzler M., Fritsche I. Absolute moral standards and global identity as independent predictors of collective action against global injustice. European journal of social psychology. 2015. Vol. 45. Issue 7. P. 918-930.

4. May D., Chang Y., Shao R. Does Ethical Membership Matter? Moral Identification and Its Organizational Implications. Journal of applied psychology. 2015. Vol. 100. Issue 3. P. 681-694.

5. Turner-Zwinkels F., van Zomeren M., Postmes T. The moral dimension of politicized identity: Exploring identity content during the 2012 Presidential Elections in the USA. British journal of social psychology. 2017. Vol. 56. Issue 2. P. 416-436.

6. Козин Н. Г. Идентификация. История. Человек. Вопросы философии. 2011. № 1. С. 37-48.

7. Danilyan O. G., Dzeban A. P., Kalinovsky Y. Y., Kalnytskyi E. A., Zhdanenko S. B. Personal information rights and freedoms within the modern society. Infomatologia. 2018. № 51 (1-2). P. 24-33.

8. Данильян О. Г., Дзьобань О. П. Інформаційне суспільство: морально-етичний дискурс. Інформація і право. 2014. № 1 (10). С. 16-25.

9. Онищук О. Сучасна людина у просторі віртуальної реальності: особливості соціально-культурної трансформації. Вісник Національного університету «Львівська політехніка». Філософьькі науки. 2014. № 780. С. 34-39.

10. Білогур В. Сучасна людина як «рефлексивна монада». Versus. 2014. № 2. С. 67-72.

11. Труфанова Е. О. Человек в лабиринте идентичностей. Вопросы философии. 2010. № 2. С. 13-22.

12. Помазова О. В. Самотність як психологічний феномен. Наукові записки Національного університету «Острозька академія». Психологія і педагогіка. 2013. Вип. 23. С. 206-214.

13. Попелюшко Р. П. Самотність - як проблема соціалізації особистості в суспільстві. Збірник наукових праць Хмельницького інституту соціальних технологій Університету «Україна». 2013. № 2. С. 212-216.

14. Доній Н. Є. Самотність як територія ризику суспільного життя людини. Філософрія і політологія в контексті сучасної культури. 2014. Вип. 7. С. 55-60.

15. Липовецки Ж. Эра пустоты: Эссе о современном индивидуализме; пер. с фр. В. В. Кузнецова. Санкт-Петербург: Владимир Даль, 2001. 330 с.

16. Бек У. Что такое глобализация?: Ошибки глобализма - ответы на глобализацию; пер. с нем. А. Григорьева и В. Седельника. Москва: Прогресс-традиция, 2001. 303 с.

17. Ситкевич Н. В. Особенности трансформации нравственных ценностей в условиях информационного общества: этико-философрский анализ: дис. ... канд. филос. наук. Новомосковск, 2011. 139 с.

18. Хейзинга Й. Homo Ludens. В тени завтрашнего дня; пер. с нидерл. В. Ошиса. Москва: АСТ, 2004. 539 с.

19. Бодрийяр Ж. Соблазн; пер. с фр. А. Гараджи. Москва: Ad marginem, 2000. 317 с.

20. Бодрийяр Ж. Символический обмен и смерть; пер. с фр. и вступ. ст. С. Н. Зенкина. М.: Добросвет, 2000. 389 с.

21. Козловски П. Культура постмодерна; пер. с нем. Москва: Республика, 1997. 238 с.

22. Хабермас Ю. Демократия. Разум. Нравственность: Московские лекции и интервью. Москва: АО «Ками»: Изд. центр «Academia», 1995. 244 с.

23. Хабермас Ю. Моральное сознание и коммуникативное действие; пер. с нем. под ред. Д. В. Скляднева. СанктПетербург: Наука, 2000. 377 с.

$127 \mathrm{c}$.

24. Хабермас Ю. От картин мира к жизненному миру; пер. с нем. Д. Мироновой. 2-е изд. Москва: Идея-Пресс, 2015.

\section{References}

1. Kahane, G., Everett, J., Earp, B. (2015).Utilitarian judgments in sacrificial moral dilemmas do not reflect impartial concern for the greater good. Cognition, Vol. 134, 193-209 [in English]. 
2. Greene, JD. (2015). The rise of moral cognition. Cognition, Vol. 135, 39-42 [in English].

3. Barth, M., Jugert, P., Wutzler, M., Fritsche, I. (2015). Absolute moral standards and global identity as independent predictors of collective action against global injustice. European journal of social psychology, Vol. 45, issue 7, 918-930 [in English].

4. May, D., Chang, Y., Shao, R. (2015). Does Ethical Membership Matter? Moral Identification and Its Organizational Implications. Journal of applied psychology, Vol. 100, issue 3, 681-694 [in English].

5. Turner-Zwinkels, F., van Zomeren, M., Postmes, T. (2017). The moral dimension of politicized identity: Exploring identity content during the 2012 Presidential Elections in the USA. British journal of social psychology, Vol. 56, issue 2, 416-436 [in English].

6. Kozin, N.G. (2011). Identifikatsiya. Istoriya. Chelovek. Voprosyi filosofii - Questions of philosophy, 1, 37-48 [in Russian].

7. Danilyan, O. G., Dzeban, A. P., Kalinovsky, Y. Y., Kalnytskyi, E. A., Zhdanenko, S. B. (2018). Personal information rights and freedoms within the modern society. Infomatologia, 51 (1-2), 24-33 [in English].

8. Danylian, O.G., Dzoban, O.P. (2014). Informatsiine suspilstvo: moralno-etychnyi dyskurs. Informatsiia i pravo Information and right, 1 (10), 16-25 [in Ukrainian].

9. Onyshchuk, O. (2014). Suchasna liudyna u prostori virtualnoi realnosti: osoblyvosti sotsialno-kulturnoi transformatsii. Visnyk Natsionalnoho universytetu "Lvivska politekhnika». Filosofski nauky - Bulletin of the Lviv Polytechnic National University. Philosophical sciences, 780, 34-39 [in Ukrainian].

10. Bilohur, V. (2014). Suchasna liudyna yak «refleksyvna monada». Versus - Versus, 2, 67-72 [in Ukrainian]. Russian].

11. Trufanova, E.O. (2014). Chelovek v labirinte identichnostey. Voprosyi filosofii - Questions of philosophy, 2, 3-22 [in

12. Pomazova, O.V. (2013). Samotnist yak psykholohichnyi fenomen. Naukovi zapysky Natsionalnoho universytetu «Ostrozka akademiia». Psykholohiia i pedahohika - Scientific notes of the National University «Ostroh Academy». Psychology and pedagogy, 23, 206-214 [in Ukrainian].

13. Popeliushko, R.P. (2013). Samotnist - yak problema sotsializatsii osobystosti v suspilstvi. Zbirnyk naukovykh prats Khmelnytskoho instytutu sotsialnykh tekhnolohii Universytetu «Ukraina» - Collection of scientific works of the Khmelnytsky Institute of Social Technologies of the University «Ukraine», 2, 212-216 [in Ukrainian].

14. Doniy, N.le. (2014). Samotnist yak terytoriia ryzyku suspilnoho zhyttia liudyny. Filosofiia i politolohiia $v$ konteksti suchasnoi kultury - Philosophy and political science in the context of modern culture, 7, 55-60 [in Ukrainian].

15. Lipovetski, Zh. (2001). Era pustotyi: Esse o sovremennom individualizme. Sankt-Peterburg: Vladimir Dal [in Russian]. [in Russian].

16. Bek, U. (2001). Chto takoe globalizatsiya?: Oshibki globalizma - otvetyi na globalizatsiyu. Moskva: Progress-traditsiya

17. Sitkevich, N.V. (2011). Osobennosti transformatsii nravstvennyih tsennostey v usloviyah informatsionnogo obschestva: etiko-filosofskiy analiz. Candidate's thesis. Novomoskovsk [in Russian].

18. Heyzinga, Y. (2004). Homo Ludens. V teni zavtrashnego dnya. Moskva: AST [in Russian].

19. Bodriyyar, Zh. (2000). Soblazn. Moskva: Ad marginem [in Russian].

20. Bodriyyar, Zh. (2000). Simvolicheskiy obmen i smert. Moskva: Dobrosvet [in Russian].

21. Kozlovski, P. (1997). Kultura postmoderna. Moskva: Respublika [in Russian].

22. Habermas, Yu. (1995). Demokratiya. Razum. Nravstvennost: Moskovskie lektsii i intervyu. Moskva: AO «Kami»: Izd. tsentr «Academia» [in Russian].

23. Habermas, Yu. (2000). Moralnoe soznanie i kommunikativnoe deystvie. Sankt-Peterburg: Nauka [in Russian].

24. Habermas, Yu. (2015). Ot kartin mira k zhiznennomu miru. Moskva: Ideya-Press [in Russian]. 